DOI https://doi.org/10.36059/978-966-397-241-1-28

Магрламова К. Г.

доктор педагогічних наук, доцент,

доцент кафедри мовної підготовки міжнародного факультету

Дніпровський державний медичний університет

м. Дніпро

\title{
ПРОБЛЕМА ПРОФЕСІЙНОЇ ПІДГОТОВКИ МАЙБУТНІХ ЛІКАРІВ У КОНТЕКСТІ ІНТЕГРАЦІЙНИХ ПРОЦЕСІВ У МЕДИЧНІЙ ОСВІТІ УКРАЇНИ З ВИВЧЕННЯМ ЗАРУБІЖНОГО ДОСВІДУ НА ПРИКЛАДІ ВЕЛИКОЇ БРИТАНІЇ
}

У статті відображені основні проблеми професійної підготовки майбутніх лікарів та шляхів виходу з кризової ситуації та побудови нової моделі, наближеної до світових стандартів. Показана необхідність інтегрування національної системи медичної освіти в умовах глобалізації та вивчення зарубіжного досвіду професійної підготовки майбутніх лікарів у провідних навчальних закладах світу. Актуальним у контексті досліджуваної проблеми є досвід Великої Британії, де підготовка майбутніх лікарів здійснюється відповідно до світових стандартів та спрямована на формування професійної еліти суспільства та показано приклад основних стратегій розвитку медичної освіти у Великій Британії.

\section{Вступ}

Вітчизняна система охорони здоров'я нині перебуває в пошуку зміни парадигми базової середньої та вищої медичної освіти. Саме тому, в умовах стрімкого розвитку інноваційних технологій та доказової медицини, впровадження в практику роботи закладів охорони здоров'я нових методів лікування і діагностики захворювань, новітніх інформаційних і сучасних медичних технологій, на часі гостро стоїть питання реформування медичної галузі. Престиж британських університетів серед молоді як Західної, так і Східної Європи залишається високим і є одним з основних прикладів для поліпшення та запровадження змін у професійній медичній освіті . Варто вказати на перші місця вищих навчальних закладів Великої Британії серед світових рейтингів: Академічного рейтингу світових 
університетів (Academic Ranking of World Universities), QS-рейтингу та інших. Підвищення якості професійної підготовки майбутніх лікарів відповідно до світових і загальноєвропейських стандартів 3 метою посилення конкурентоспроможності вітчизняної вищої медичної освіти, оптимізації умов для міжнародної мобільності студентів-медиків на вітчизняному та міжнародному ринках праці зумовлені проголошенням Україною курсу на євроінтеграцію.

\section{1. Аналіз останніх досліджень і публікацій, який дозволяє охарактеризувати основні стратегії розвитку медичної освіти}

та показати вплив інтеграційних процесів в медичній освіті

Підвищення якості професійної підготовки майбутніх лікарів відповідно до світових і загальноєвропейських стандартів з метою посилення конкурентоспроможності вітчизняної вищої медичної освіти, оптимізації умов для міжнародної мобільності студентівмедиків на вітчизняному та міжнародному ринках праці зумовлені проголошенням Україною курсу на євроінтеграцію. Одним із можливих шляхів запровадження якісних змін у професійній підготовці майбутніх лікарів $€$ врахування результатів наукових пошуків. Так, питання філософії вищої освіти вивчали в Україні: В. Андрущенко, І. Зязюн, В. Кремень та ін.; концептуальні підходи до реформування та інноваційного розвитку освіти досліджували: Л. Гриневич, М. Згуровський, В. Луговий, Г. Хорунжий та ін.; проблематику професійної освіти та професійної компетентності розглядали: Н. Бібік, В. Биков, В. Гриньова, Л. Лук'янова, Н. Ничкало, О. Овчарук, О. Пометун, Г. Пустовіт, О. Семеног, А. Хуторський; проблеми порівняльної педагогіки розробляли: Н. Авшенюк, Б. Вульфсон, Т. Десятов, О. Джуринський, Л. Дяченко, А. Сбруєва, О. Локшина, О. Матвієнко, О. Огієнко, Н. Постригач, Л. Пуховська та ін. У сучасній професійній педагогіці активно здійснюються порівняльнопедагогічні дослідження підготовки фахівців. Проблеми теорії і практики підготовки фахівців різних напрямів та спеціальностей у Великій Британії вивчали: Н. Яцишин (Професійнопедагогічна підготовка вчителів у Великій Британії (90-і роки XX століття), 1998); Н. Бідюк (Розвиток змісту та форм організації підготовки бакалаврів інженерії в університетах Великої Британії, 2000); О. Демченко (Теорія та практика сімейного виховання у Великій Британії (історико-педагогічний аспект), 2001); О. Пічкар (Система підготовки фахівців соціальної роботи у Великій Британії, 2002); 0. Черевко (Маргарет Тетчер та їі реформаторська діяльність 
на чолі консервативного уряду Великої Британії (1979-1990рр.), 2002); Я. Полякова (Теорія і практика екологічного виховання учнівської молоді у Великій Британії (етнопедагогічний аспект), 2005); С. Старовойт (Професійна підготовка фахівців з охорони та захисту навколишнього середовища у вищих навчальних закладах Великої Британії, 2005); О. Загайко (Підготовка працівників соціальних служб для середніх загальноосвітніх навчальних закладів Великої Британії, 2008); О. Мілютіна (Полікультурна освіта учнів середньої загальноосвітньої школи у Великій Британії, 2008); 0. Оверчук (Політика Великої Британії у контексті формування інформаційного суспільства, 2009); Г. Погромська (Розвиток релігійної освіти у середніх школах Великої Британії, 2009); Н. Костенко (Організація профільного навчання у старшій школі Великої Британії, 2010); І. Романко (Педагогічні засади діалогічної взаємодії вчителя й учнів у загальноосвітніх навчальних закладах Великої Британії, 2010); I. Сидор (Організаційно-педагогічні умови дозвіллєвої діяльності студентів у педагогічних коледжах Великої Британії, 2010); В. Бойко (Система післядипломної педагогічної освіти у Великій Британії в контексті неперервної освіти, 2011); I. Паламаренко (Професійна підготовка сімейних лікарів у вищих медичних школах Великої Британії, 2012); Л. Логуш (Тенденції розвитку медичної освіти в освітній політиці Європейського Союзу, 2016). Окремі аспекти підготовки та професійної діяльності лікарів в Україні досліджено у дисертаційних дослідженнях: Л. Григорчук (Гігієнічні аспекти професійної адаптації студентів до умов навчання у вищих медичних навчальних закладах та шляхи іiі оптимізації, 2000); А. Степаненко (Система забезпечення якості медичної допомоги населенню України та наукове обгрунтування ії реалізації, 2001); Л. Руденко (Формування системи медичних знань у процесі підготовки педагога-дефектолога до корекційної роботи в закладах спеціальної освіти, 2005); I. Круковська (Становлення і розвиток медичної освіти на Волині (XIX - 30-ті роки XX ст.), 2007); Р. Іваненко (Організаційно-педагогічні умови професійної орієнтації старшокласників на медичні спеціальності, 2008); М. Кушик (Дидактичні основи фахової підготовки студентів у медичних навчальних закладах України (друга половина XIX - початок XX ст., 2009); I. Солопова (Медичне обслуговування як форма соціального захисту населення України, 2009); О. Неловкіна-Берналь (Формування професійної спрямованості студентів медичних спеціальностей на початковому етапі навчання, 2010); М. Петрус 
(Вплив професійних стереотипів на діяльність лікарів-терапевтів, 2011); С. Тихолаз (Педагогічні умови розвитку професійної спрямованості студентів вищих медичних навчальних закладів, 2011); Н. Шигонська (Підготовка студентів медичних спеціальностей до професійної взаємодії засобами моделювання комунікативних ситуацій, 2011). Значний інтерес становлять результати досліджень науковців Великої Британії щодо підготовки майбутніх сімейних лікарів: М. Калюс (Medical Education Guide, 1999); Г. Катто (Interface between university and medical school, 2000); Г. Флорес (The Teaching of Cultural Issues in U.S. and Canadian Medical Schools, 2000); М. Бірман (Random comparison of virtual patient models in the context of teaching communication skills, 2001); Дж. Ворд (Communication and information technology in medical education, 2001); К. Бойлен (A new paradigm for medical schools a century after Flexner's report, 2002); С. Вілліс (Small-group work and assessment in a PBL curriculum: a qualitative and quantitative evaluation of student perceptions of the process of working in small groups and its assessments, 2002); П. Оузах (Undergraduate medical education: thoughts on future challenges, 2002); Д. Вуд (Evaluating the outcomes of undergraduate medical education, 2003); К. Хак (Integrating the Art and science of medical practice: Innovations in teaching medical communication skills, 2004); A. Xoy (New perspectives - approaches to medical education at four UK medical schools, 2004); Р. Цігер (Towards continuous medical education. Journat of General Internal Medicine, 2005); Б. Томпсон, В. Шнайдер, П. Хайдет, Р. Лівайн, К. МакМахон, Л. Перковскі, Б. Ріхардс (Team-based learning at ten medical schools: two years later, 2007); Р. Іллавей (AMEE Guide 32: e-Learning in medical education Part 1: Learning, teaching and assessment, 2008); М. МакКлаф (Good Practice. Communication Skills in English for medical Practitioner, 2008); С. МакКартер (Oxford English for Careers. Medicine 1. Student's book, 2009); Д. Пармілє, Д. ДеСтефен, Н. Боргес (Medical students' attitudes about team-based earning in a pre-clinical curriculum, 2009), А. Чоударі (Teaching communications skills to medical students: Introducing the fine art of medical practice, 2015).

Одним із можливих шляхів запровадження якісних змін у професійній підготовці майбутніх лікарів $є$ врахування результатів наукових пошуків. Так, питання філософії вищої освіти вивчали в Україні: В. Андрущенко, І. Зязюн, В. Кремень та ін.; концептуальні підходи до реформування та інноваційного 29 розвитку освіти досліджували: Л. Гриневич, М. Згуровський, В. Луговий, Г. Хорунжий 
та ін.; проблематику професійної освіти та професійної компетентності розглядали: Н. Бібік, В. Биков, В. Гриньова, Л. Лук'янова, Н. Ничкало, О. Овчарук, О. Пометун, Г. Пустовіт, О. Семеног, А. Хуторський; проблеми порівняльної педагогіки розробляли: Н. Авшенюк, Б. Вульфсон, Т. Десятов, О. Джуринський, Л. Дяченко, А. Сбруєва, О. Локшина, О. Матвієнко, О. Огієнко, Н. Постригач, Л. Пуховська та ін.

У сучасній професійній педагогіці активно здійснюються порівняльно педагогічні дослідження підготовки фахівців. Проблеми теорії і практики підготовки фахівців різних напрямів та спеціальностей у Великій Британії вивчали: Н. Яцишин (Професійно-педагогічна підготовка вчителів у Великій Британії (90-і роки XX століття), 1998); Н. Бідюк (Розвиток змісту та форм організації підготовки бакалаврів інженерії в університетах Великої Британії, 2000); О. Демченко (Теорія та практика сімейного виховання у Великій Британії (історикопедагогічний аспект), 2001); 0. Пічкар (Система підготовки фахівців соціальної роботи у Великій Британії, 2002); О. Черевко (Маргарет Тетчер та ії реформаторська діяльність на чолі консервативного уряду Великої Британії (1979-1990рр.), 2002); Я. Полякова (Теорія і практика екологічного виховання учнівської молоді у Великій Британії (етнопедагогічний аспект), 2005); С. Старовойт (Професійна підготовка фахівців з охорони та захисту навколишнього середовища у вищих навчальних закладах Великої Британії, 2005); 0. Загайко (Підготовка працівників соціальних служб для середніх загальноосвітніх навчальних закладів Великої Британії, 2008); О. Мілютіна (Полікультурна освіта учнів середньої загальноосвітньої школи у Великій Британії, 2008); О. Оверчук (Політика Великої Британії у контексті формування інформаційного суспільства, 2009); Г. Погромська (Розвиток релігійної освіти у середніх школах Великої Британії, 2009); Н. Костенко (Організація профільного навчання у старшій школі Великої Британії, 2010); І. Романко (Педагогічні засади діалогічної взаємодії вчителя й учнів у загальноосвітніх навчальних закладах Великої Британії, 2010); I. Сидор (Організаційно-педагогічні умови 30 дозвіллєвої діяльності студентів у педагогічних коледжах Великої Британії, 2010); В. Бойко (Система післядипломної педагогічної освіти у Великій Британії в контексті неперервної освіти, 2011); I. Паламаренко (Професійна підготовка сімейних лікарів у вищих медичних школах Великої Британії, 2012); Л. Логуш (Тенденції розвитку медичної освіти в освітній політиці Європейського Союзу, 2016). 
Проте результати аналізу наукових та інших джерел дали змогу стверджувати, що теоретико-методичні основи професійної підготовки майбутніх лікарів у вищих медичних навчальних закладах Великої Британії українськими науковцями досліджено не достатньо. Аналіз законодавчих, документальних i літературних джерел дозволив здійснити теоретичне узагальнення досліджуваної проблеми професійної підготовки майбутніх лікарів у медичних закладах вищої освіти Великої Британії та виявити певні суперечності, зокрема між: - потребами сучасного глобалізованого суспільства й недостатнім 32 забезпеченням нової якості професійної підготовки медичної еліти у Великій Британії та інших країнах світу; необхідністю грунтовного аналізу інноваційних ідей професійного навчання майбутніх лікарів у Великій Британії та відсутністю узагальненого вивчення досвіду у вітчизняній медико-педагогічній теорії; - потребами суспільства у якісних змінах системи медичної освіти України відповідно до європейських стандартів та недостатністю наукового обгрунтування теоретико-методичних засад професійної підготовки майбутніх лікарів; - якісним розвитком вищої медичної освіти в Україні та відсутністю належного нормативноправового, науково-методичного, організаційно педагогічного забезпечення підготовки майбутніх лікарів; - рівнем взаємодії між навчальними установами у медичній галузі та соціальними інститутами охорони здоров'я, відсутністю якісного моніторингу потреб у конкурентоздатних фахівцях; - вимогами ринку праці й результатами Brexit та можливостями мобільності фахівців у професійному медичному просторі; - об'єктивною потребою системного вивчення досвіду медичної підготовки у Великій Британії й відсутністю його узагальнення у вітчизняній науці.

Актуальність означеної проблеми, її недостатня розробленість, відсутність їі цілісного наукового аналізу у порівняльній педагогіці, об'єктивна потреба у теоретичному та практичному осмисленні інноваційного зарубіжного досвіду, необхідність його екстраполяції в площину національної системи вищої медичної освіти зумовили вибір теми монографії.

Аналіз наукової літератури дозволив охарактеризувати основні стратегії розвитку медичної освіти у Великій Британії, який Україна може взяти за приклад: по-перше це в результат екстраполяції діяльності міжнародних громадських медичних організацій i об'єднань було визначено: координація діяльності законодавчих органів через участь в експертних комітетах з метою діалогу між 
законодавчою базою та ЗВО; спрямованість рішень міжнародних організацій на розвиток медичної освіти різних рівнів; забезпечення здійснення медико-соціального страхування та підготовки фахівців відповідного напряму діяльності; захист інтересів представників медичних професій; підготовка майбутніх лікарів до здійснення різних видів медичної допомоги та страхування на основі документів міжнародних організацій; екстраполяція Міжнародного кодексу медичної етики у зміст освіти майбутніх лікарів; впровадження рішень міжнародних організацій щодо політики «Здоров'я для всіх» у медичну освіту; забезпечення глобальної модернізації медичної освіти через мережу міжнародних медичних об'єднань; імплементація у зміст професійної підготовки майбутніх лікарів документів ООН щодо прав людини; регламентація практичної діяльності лікаря у правовій площині міжнародними документами; єдність ціннісної характеристики медичної культури, закладеної міжнародним кодексом щодо етичних обов'язків лікаря; дотримання міжнародних документів щодо захисту прав пацієнтів; включення майбутніх лікарів у діяльність міжнародних організацій з метою здійснення співробітництва в галузі медичної науки; розвиток медичних технологій у системі безперервної медичної освіти.

Таким чином, діяльність міжнародних організацій та основні положення міжнародних документів щодо охорони здоров'я мають методологічне значення для дослідження системи медичної освіти у Великій Британії.

По-друге аналіз наукової літератури та стандартів, визначених різними медичними міжнародними організаціями, дозволив охарактеризувати узагальнений підхід. Визначені стандарти представлені на рис. 2.

Вплив інтеграційних процесів у світі на визначення стандартів вищої медичної освіти Великої Британії передбачає вільне переміщення лікарів і відповідне визнання їхніх дипломів та сертифікатів. Цими питаннями займається Консультативний комітет з питань медичної підготовки, який забезпечує створення стандартів базової і післядипломної медичної підготовки в Європейському Союзі та двосторонній зв'язок між європейськими медичними організаціями, університетами, національними урядами і Єврокомісією. Учервні 1975 року Європейське економічне співтовариство, в даний час Європейський Союз, видало директиву про вільне переміщення лікарів і первісне визнання їхніх дипломів та сертифікатів, яка відкрила можливість вільно переміщуватись 
лікарям уже між дев'ятьма державами Європи. У 1976 році Рада Міністрів ЄС запропонувала спільну Програму дій розвитку освіти, що включала в себе: доступ до вищої освіти, визнання дипломів, загальні навчальні програми, інформаційну політику [1].

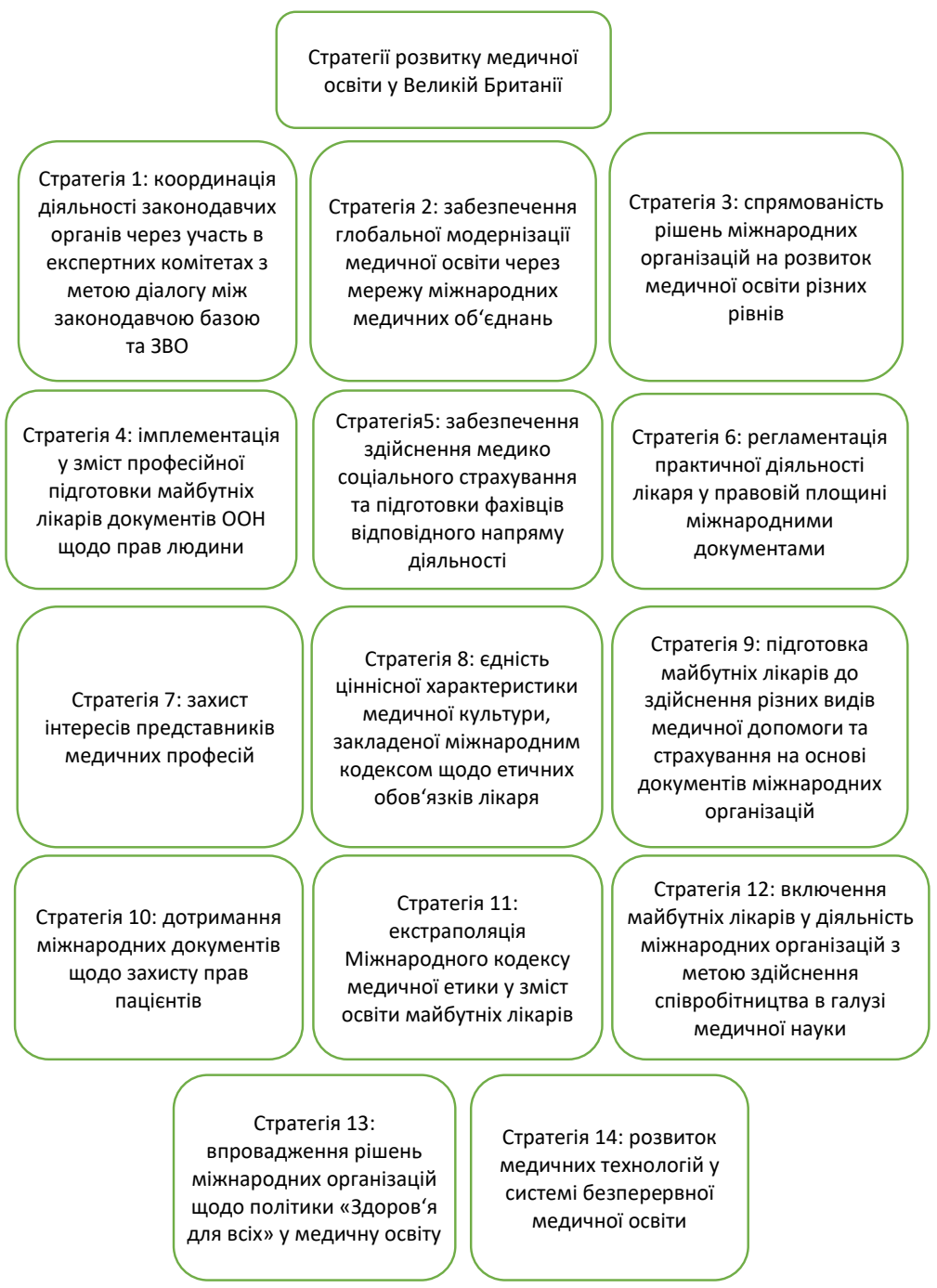

Рис. 1. Стратегії розвитку медичної освіти у Великій Британії 


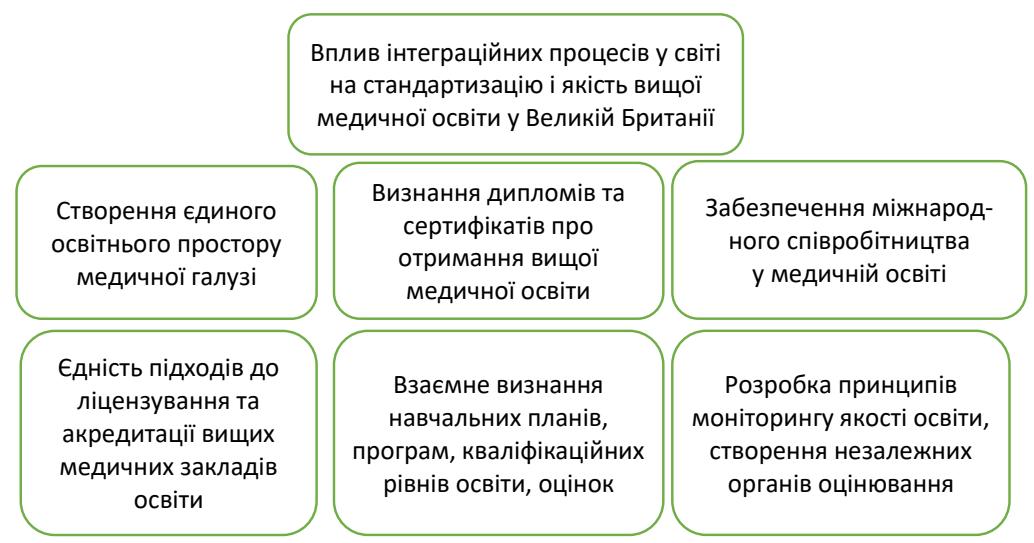

\section{Рис. 2. Вплив інтеграційних процесів у світі на стандартизацію і якість вищої медичної освіти у Великій Британії}

Суттєвим для впровадження стратегічного завдання Болонського процесу було: впровадження дворівневої системи вищої освіти (Bachelor/Master) та докторських програм (Philosophia Doctor - PhD); прийняття системи зрозумілих і доступних для співвіднесення ступенів, у тому числі й Додатка до диплома; запровадження системи кредитів за типом European Credit Transfer and Accumulation system (ECTS); забезпечення якості освіти відповідно до європейських стандартів [1, с. 7].

Наступним етапом стандартизації вищої медичної освіти у Великій Британії, котрий відбувається під впливом глобалізації та інтернаціоналізації європейської та світової вищої освіти, є питання взаємного визнання навчальних планів і програм, кваліфікаційних рівнів освіти, оцінок тощо. Важливим є порозуміння стосовно підходів до контролю якості освіти, питань ліцензування i акредитації закладів вищої освіти різних типів і рівнів у різних країнах світу. Відповідно, серед новітніх тенденцій розвитку вищої школи як інтернаціонального явища особливе місце займає інтеграція (наприклад, євроінтеграція) вищої освіти, що має на меті створення єдиного освітнього простору; основні завдання такого процесу: розвиток науки й інтенсивність нарощування наукового потенціалу (у США фінансування наукових досліджень становить понад $3 \%$ валового національного доходу, в Європі - у середньому 1,9\%); збільшення кількості підготовлюваних фахівців з вищою освітою (в Європі цей показник удвічі менший, ніж у США); 
збільшення кількості іноземних студентів (у США їх більше півмільйона, в Європі - у кілька разів менше). Ці ознаки, на думку науковців, зумовлюють упровадження міжнародних стандартизованих систем моніторингу якості освіти; орієнтацію роботи закладів вищої освіти на наукові досягнення й інновації як джерело фінансування і навчальної роботи, і закладу в цілому; подальшу демократизацію системи його керування; ефективнішу комп'ютеризацію та інформатизацію діяльності закладу, спеціальностей, факультетів, кафедр; одночасне підвищення рівня фундаменталізації навчання і професіоналізації випускників [2, с. 24] .

Вплив інтеграційних процесів у світі на стандартизацію вищої медичної освіти у Великій Британії сприяв міжнародному співробітництву в галузі медицини. Так, більшість європейських і світових вищих навчальних закладів, у тому числі вищих медичних закладів освіти Великої Британії укладають угоди про співпрацю, які стосуються різних аспектів викладання і навчання. Здебільшого ці угоди пов'язані з обміном студентами і викладачами. У деяких випадках ці зв'язки переростають у консорціуми й університетські мережі. Як правило, такі об'єднання навчальних закладів мають дуже обмежені права. Їх розглядають переважно як добровільні об'єднання 3ВО для виконання конкретних освітніх проектів. Але робота з погодження вимог і освітніх стандартів, що проводиться учасниками консорціумів і університетських мереж, поза сумнівом, сприяє просуванню ідеї інтернаціоналізації вищої освіти [3, с. 15].

Ці заходи були спрямовані на підвищення якості освіти як основного критерію конкурентоспроможності майбутніх фахівців, у тому числі медиків, що підтверджується рішеннями конференції ЮНЕСКО, котра відбулася у Парижі (1998р.), де було прийнято «Всесвітню декларацію про вищу освіту для XXI століття», яка містила більш деталізоване й універсальне, на нашу думку, тлумачення поняття «якість вищої освіти». У ній зазначено, що «якість у вищій освіті $є$ багатомірною концепцією, котра повинна охоплювати всі його функції та види діяльності: навчальні та академічні програми; наукові дослідження та стипендії; укомплектування кадрами; тих, хто навчається; матеріально технічну базу та устаткування; роботу на благо суспільства» [6, с. 6].

Характерною особливістю розвитку вищої медичної освіти у Великій Британії науковці відзначають проведення радикальних якісних змін (друга половина XX - початок XXI століття). Підтвердження цієї думки знаходимо у працях I. Паламаренко, яка 
досліджувала специфіку професії «Сімейний лікар - лікар загальної практики» в Об'єднаному Королівстві. Було проаналізовано організаційні засади професійної підготовки лікарів. Особлива увага приділялась професійній орієнтації та професійному відбору абітурієнтів до вступу, що характеризується високим конкурсом, обмеженою кількістю місць та високими академічними вимогами [6]. До таких якісних змін відносяться нові підходи до контролю якості освітніх послуг, що здійснюють як національні, так i міжнародні агентства. Найбільш відомими й визнаними міжнародними національними організаціями 3 контролю якості освіти, у тому числі медичної, є: - Агентство із забезпечення якості (Велика Британія) - Quality Assurance Agency (QAA), яке проводить регулярні атестації всіх англійських 3ВО, а також акредитує всі міжнародні програми, в яких вони беруть участь, якщо присуджуються їх дипломи і ступені. - Акредитовані програми MBA (Велика Британія) - Accredited Master: Business Administration (AMBA). Ця агенція акредитує програми магістра, адміністрування MBA англійських і зарубіжних 3ВО. Вона $\epsilon$ найбільш престижною системою акредитації в світі для програм МВА. Вища медична школа Великої Британії, як і багато інших університетських ступенів, має внутрішні критерії оцінювання. Ця практика відрізняється від, наприклад, Сполучених Штатів Америки, де національна експертиза ліцензування практикується більше 20 років. Кожен магістрант у Великої Британії, отримуючи підсумкову оцінку в медицині $\epsilon$ предметом пильного дослідження за яким спостерігає призначений зовнішній екзаменатор. У 2003 році ряд британських медичних шкіл почали працювати разом, щоб підвищити якість діяльності щодо забезпечення в області оцінювання в рамках Партнерства Університетів медичної оцінки (UMAP). UMAP це спільний проект, що прагне до створення гарантованої якості критеріїв оцінювання у всіх медичних закладах вищої осіти Великої Британії. Забезпечення якості медичної освіти здійснює Генеральна Медична Рада Великобритані (GMC), котра має можливість повністю змінити свою оцінку будь-якого медичного студентського навчального курсу, якщо даний курс не відповідає очікуваним стандартам. У зв'язку $з$ підходами Великої Британії до отримання вищої освіти, перші ступені в галузі медицини включають інтегровану програму навчання і практики, що охоплює кілька рівнів. Остаточні підсумки кваліфікації, як правило, відповідають очікуванням кваліфікації вищої освіти на сьомому рівні (ступінь британського магістра). 
Ці ступені можуть зберігати, 3 історичних причин, «Бакалавр медицини, бакалавр хірургії» і скорочено MBChB або MBBS [5].

Таким чином, оцінка якості вищої медичної освіти виступає як важливий механізм стандартизації та забезпечення ефективності останньої, а моніторинг повинен носити системний характер. Міжнародна організація зі стандартизації ISO (International Organization for Standardization) дала таке визначення якості: «Якість - сукупність характеристик об'єкта, що відносяться до його здатності задовольняти встановлені та передбачувані потреби», воно $\epsilon$ основним у нашому дослідженні [5].

3 метою реалізації стратегічного курсу України на інтеграцію до Європейського Союзу (далі ЄС), забезпечення всебічного входження України у європейський політичний, правовий, економічний та освітній простір та створення передумов для набуття нашою державою членства у вище означеній організації Указами Президента затверджена Стратегія інтеграції України до ЄС. Україна $\epsilon$ країною-учасницею Болонського процесу, що також накладає певні вимоги до системи їі освіти. Відтак можемо сказати, що саме Болонський процес став поштовхом та засобом демократизації та інтеграції освіти, зокрема вищої освіти країни. Як відомо, підписання Болонської декларації і розпочатий етап реформування європейської вищої професійної освіти медичними школами Європи були сприйняті насторожено. В основі такої обережності - розуміння ціни помилкових дій, які можуть порушити національні системи медичної освіти, що вже склалися, і тим самим призвести до зниження рівня медичної допомоги і погіршити стан здоров'я мільйонів людей. Проте, як відомо, Болонський процес викликаний об'єктивними чинниками об'єднання Європи [4, с. 40]. Важливим для визначення стандартів вищої медичної освіти Великої Британії та актуальним напрямом розвитку співробітництва європейських країн та світового медичного товариства стало формування єдиного освітнього простору. Характерною особливістю європейської освітньої політики стала організація співробітництва між національними освітніми системами та обмін досвідом, а основною функцією - формування загальних пріоритетів, визначення механізмів співробітництва.

На проблеми стандартизації вищої медичної освіти Великої Британії мають вплив такі чинники, як розширення автономії 3В0, децентралізація і передача повноважень від центральних національних урядів регіональним органам влади і самим закладам вищої 
освіти, надають більше різноманітності в системи національної освіти, тим самим уповільнюючи їх міжнародну гармонізацію. Найлегше піддаються міжнародній стандартизації такі аспекти освіти, як структура навчального року і система оцінки знань. У питанні структури студентських і аспірантських навчальних програм спостерігається повільний рух до англо-американської моделі. Важливим підтвердженням цієї ідеї стали Сорбонська і пізніше Болонська декларації. Підписана представниками міністерства освіти Франції, Німеччини, Італії і Великої Британії на зустрічі 3 нагоди дня заснування Сорбонського університету (25 травня 1998 року), котра містить визнання прагнення країн до інтернаціоналізації через поступову уніфікацію дипломів, освітньо наукових ступенів, освітніх циклів і таким чином - до створення реального «єдиного простору європейської вищої освіти» [7].

Для вирішення практичних аспектів проблеми стандартизації вищої освіти були розроблені заходи для підвищення конкурентоспроможності майбутніх фахівців. 3 цього приводу досягненням Болонського процесу стало підписання Болонської декларації (19 липня 1999 року), до якої приєдналися 45 країн, в їх числі і Україна, метою якого було створення спільної Зони європейської вищої освіти, що мало забезпечити привабливість освіті, підвищити іiї конкурентоспроможність й забезпечити подальше розширення i розвиток Європи. Для досягнення поставлених цілей були сформульовані завдання: створення системи зрозумілих усім кваліфікаційних ступенів вищої освіти; створення системи вищої освіти, заснованої на двох рівнях.

Перший рівень передбачає підготовку студентів до використання своїх знань і умінь на ринку праці.

Другий рівень повинен грунтуватися на успішному освоєнні першого рівня; створення системи накопичення і переведення (визнання) кредитів, тобто документів про здобуту попередню освіту для продовження освіти в іншій країні; мобільність студентів, викладачів, дослідників; співпраця в галузі управління якістю; створення європейського стандарту вищої освіти [3, с. 17].

Основним документом, що регламентує процедури забезпечення якості освіти серед країн - учасниць Болонського процесу, $\epsilon$ Стандарти та норми забезпечення якості в Європейському просторі вищої освіти. Цей документ, згідно з яким гарантування якості освіти здійснюється на інституціональному, національному та європейському рівнях, містить систему забезпечення якості вищої 
освіти: стандарти та норми щодо забезпечення якості освіти на рівні 3В0; стандарти та норми щодо зовнішнього забезпечення якості освіти (на рівні держави); стандарти та норми щодо міжнародного забезпечення якості освіти [8, с. 83].

Усі стандарти та норми базуються на основних принципах гарантування внутрішньої та зовнішньої якості вищої освіти в європейському та світовому освітньому просторі: відповідальність ЗВО за якість освіти та її гарантування; урахування інтересів суспільства щодо гарантування якості та забезпечення дотримання стандартів вищої освіти; удосконалення та покращення навчальних програм з огляду на входження у європейський освітній простір; оптимізація структури інституцій, що реалізують навчальні програми, та підвищення ефективності їхньої діяльності; прозорість зовнішньої експертизи щодо оцінювання якості освіти; удосконалення системи звітності ЗВО та іï прозорість, включаючи звітність щодо інвестування в освіту державних та приватних коштів; гарантування якості з огляду на їі відповідність умовам результативності; можливість ЗВО підтверджувати якість освіти як всередині країни, так і за кордоном. Використовувані методи оцінювання якості не повинні стримувати розвиток освіти та їі інноваційність [8, с. 83-109].

Таким чином, вплив інтеграційних процесів у світі на стандарти та якість вищої медичної освіти Великої Британії спричинили такі заходи: створення єдиного освітнього простору медичної галузі; визнання дипломів та сертифікатів про отримання вищої медичної освіти; єдність підходів до ліцензування та акредитації вищих медичних закладів освіти; забезпечення міжнародного співробітництва у медичній освіті; взаємне визнання навчальних планів, програм, кваліфікаційних рівнів освіти, оцінок; розробка принципів моніторингу якості освіти, створення незалежних органів оцінювання.

\section{2. Іншомовна освіта, як головний чинник підвищення якості професійної підготовки майбутніх лікарів}

Актуальність питання впровадження іншомовної освіти як провідної основи й обов'язкової умови професійної підготовки майбутніх лікарів у медичних закладах вищої освіти Великої Британії обумовлена такими чинниками: відповідно до міжнародного документу «Освіта і навчання 2020» (Education\&Training 2020), прийнятого в 2009 р., у Великій Британії обов'язковим $є$ вивчення 
двох іноземних мов, це обумовлено загальною тенденцією до гуманізації освіти та полікультурного розвитку особистості на основі вивчення мови та культури інших країн, що є сутністю іншомовної освіти; для студентів медичних закладів вищої освіти ця програма посилюється необхідністю налагоджувати комунікативні стосунки 3 пацієнтами та колегами 3 інших країн; у Англії, де домінуючою мовою $\epsilon$ англійська мова, використовується ще близько 300 мов малих спільнот, найбільш поширеними $є$ урду, кантонська, пенджабська, бенгальська, арабська, турецька, російська, іспанська, португальська, гуджараті, хінді та польська мови. Щоб визначити забезпеченість викладання мов мінорних спільнот у країні прийнято Національну мовну стратегію, де наголошується на необхідності впровадження іншомовної освіти; відповідно до національної мовної політики Великої Британії та у зв'язку з постійним збільшенням кількості іноземних студентів на медичних факультетах університетів виникла необхідність у такому рівні оволодіння студентами іноземною мовою, яка дозволяє здійснювати успішну професійну підготовку, а також ознайомлювати майбутніх лікарів 3 національними/регіональними тенденціями та забезпечувати високий рівень міжкультурної компетентності у мовному забезпеченні 3ВО. Таким чином, виокремлюємо три основних чинника, що визначають необхідність здійснення у вищій медичній освіті Великої Британії іншомовної освіти. Об'єднання Європи та поглиблення міжнародного 99 співробітництва, попит європейського ринку праці висувають високі вимоги до володіння іноземними мовами. Процес їх вивчення перетворюється в істотний елемент загальної освіти і значення його в європейських освітніх закладах постійно зростає. У вимогах Європейського Союзу міститься положення про те, що якнайбільше громадян Європи повинні володіти двома іноземними мовами, крім рідної [16].

Одним із завдань впровадження іншомовної освіти у медичних університетах Великої Британії $є$ збереження європейського та світового культурного багатства і мовної різноманітності, що грунтуються на культурній спадщині і національних традиціях. Пріоритетним розвитком вищої освіти $\epsilon$ розв'язання завдань Болонської декларації, щодо створення в країнах ЄС до 2010 р. єдиного загальноєвропейського простору вищої освіти (The European Higher Education Area), котрий стосується процесу організації європейського дослідницького простору (European Research Area). Зокрема: підвищення якості підготовки фахівців 
вищої кваліфікації, зміцнення довіри між суб'єктами навчання i виховання; створення умов для формування конкурентоспроможної системи вищої освіти; встановлення тісних зв'язків між вищою освітою і дослідницькою системою в кожній із країн, котрі підписали Болонську декларацію [9, с. 5].

Характерною рисою освіти у Великій Британії $\epsilon$ розуміння іншомовного професійного спілкування як складового компоненту іншомовної освіти, якій притаманні певні закономірності, котрі перебувають в полі зору фахівців і реалізують реформи ії змісту й технології функціонування. Поняття професійне іншомовне спілкування розглядається Одним із завдань впровадження іншомовної освіти у медичних університетах Великої Британії $\epsilon$ збереження європейського та світового культурного багатства i мовної різноманітності, що грунтуються на культурній спадщині і національних традиціях.

Пріоритетним розвитком вищої освіти $\epsilon$ розв'язання завдань Болонської декларації, щодо створення в країнах ЄС до 2010 р. єдиного загальноєвропейського простору вищої освіти (The European Higher Education Area), котрий стосується процесу організації європейського дослідницького простору (European Research Area). Зокрема: підвищення якості підготовки фахівців вищої кваліфікації, зміцнення довіри між суб'єктами навчання i виховання; створення умов для формування конкурентоспроможної системи вищої освіти; встановлення тісних зв'язків між вищою освітою і дослідницькою системою в кожній із країн, котрі підписали Болонську декларацію [9, с. 5].

Характерною рисою освіти у Великій Британії $\epsilon$ розуміння іншомовного професійного спілкування як складового компоненту іншомовної освіти, якій притаманні певні закономірності, котрі перебувають в полі зору фахівців і реалізують реформи ії змісту й технології функціонування. Поняття професійне іншомовне спілкування розглядається як особлива міжособистісна професійна взаємодія у сфері інформаційно пізнавального контакту, яка передбачає обмін інформацією з урахуванням можливостей пізнавального й емоційного впливів на співрозмовника та особливостей мовленнєвого та поведінкового етикету носіїв мови [10].

Нова соціально-економічна i політична ситуація вимагає реалізації в суспільстві мовної політики в галузі іншомовної освіти, націленої на задоволення як громадських, так і особистісних потреб до оволодіння іноземними мовами. Термін «іншомовна освіта» був 
введений в науковий обіг в кінці 90-х років XX століття $Є$. Пассовим, який розглядає іноземну мову не як «навчальний предмет», а як «освітню дисципліну», вважаючи при цьому, що в іншомовній освіті органічно поєднуються такі аспекти: пізнавальний (знання іноземної культури і мови як її компонента), що розвиває (розвиток всіляких здібностей і мовленнєвих механізмів), виховний (виховання моральних якостей особистості) і навчальний (оволодіння вміннями говорити, читати, писати, слухати на іноземній мові) $[11$, c. 58].

Для розуміння мовних процесів, що відбуваються у Великій Британії, на основі аналізу педагогічної літератури, зробимо висновок, що поняття «іншомовна освіта» стало загальноприйнятим в професійному співтоваристві викладачів іноземної мови і може бути розглянуто в наступних аспектах: 1) як цілісний педагогічний процес; 2) як цінність; 3) як діяльність; 4) як результат [12, с. 5].

Нові освітні стратегії держави в галузі вищої освіти вимагають зміни мовної політики, в рамках якої передбачаються: стійкі знання в області іншомовного професійного і академічного дискурсу, що сприймаються вже не як конкурентна перевага, а як базовий універсальний навик; розвинені навички усної та писемної комунікації іноземною мовою як для професійної кар'єри, так і для міжнародної наукової діяльності; здатність презентувати результати своїх досліджень за кордоном, демонструвати міжнародний індекс цитованості, отримувати гранти на міжнародні дослідження, брати участь в міжнародних дослідницьких проектах, підвищувати рейтинг власного університету і конкурентоспроможності вищої освіти. Таким чином, якість мовної університетської освіти стає не тільки критерієм особистого успіху фахівця/дослідника, а й фактором опосередкованого впливу на економічний розвиток держави і добробут суспільства [13].

У нашому дослідження ми інтегруємо поняття «іншомовна освіта», «іншомовна компетентність», «міжкультурна компетентність». 3 позицій нового методологічного підходу здійснюється переорієнтація цілепокладання у вивченні іноземної мови. Мета полягає не у «навчанні іноземної мови» як такої, а у «іншомовній освіті», змістом якої є не тільки прагматичні знання, навички та вміння, а й розвиток особистості засобами іноземної мови при паралельному і взаємопов'язаному вивченні мови і культури, а міжкультурна парадигма представляється як онтологія сучасної мовної освіти, яка звернена до принципів формування полікуль- 
турної особистості в умовах полікультурного-мовного простору під час вивчення іноземних мов [14].

Науковцями виокремлено принципи іншомовної освіти в 3В0: принцип безперервно і послідовно іншомовної освіти (передбачає загальні концептуальні підходи до реалізації гармонізованого змісту і технологій на всіх рівнях іншомовної освіти); комунікативноміжкультурна взаємодія (забезпечує розвиток здатності до міжкультурного іншомовного спілкування); проблемності й інтерактивності організації навчального процесу (реалізується через вирішення конкретних проблем з опорою на знання, навички та вміння, отримані в різних предметних областях); фундаментальності іншомовної освіти (передбачає засвоєння студентами глибоких і всебічних знань, які складають необхідну основу для розвитку високого професіоналізму і забезпечують мобільність особистості в динамічно мінливих умовах життя); забезпечення міжнародно стандартного рівня навченості (означає функціональність в оволодінні іноземною мовою і культурою, відповідність міжнародним стандартам і реалізується через адекватні цілі, зміст і технології, а також об'єктивні міжнародно-стандартні способи оцінювання - дескриптори рівнів володіння іноземною мовою); позитивного корпоративізму (означає досягнення згоди i соціального партнерства учасників взаємодії і дозволяє задати професійний контекст навчального процесу, оскільки передбачає моделювання ситуацій соціально-психологічної взаємодії, регульованого ціннісно-нормативною системою майбутньої професійної діяльності); культурно-пов'язаного вивчення іноземної та рідної мов (грунтується на нерозривному зв'язку кожної окремої мови та відповідної культури і положенні, що усвідомлення форм рідної мови стає можливим за контрастом 3 досліджуваною іноземною мовою); пролонговано компетентності (передбачає спрямованість на міцні базові, інваріантні знання студентів про іншомовну культуру і пов'язані з ними стійкі мовні компетенції як основи готовності застосовувати ці знання в довгостроковій перспективі, в змінній комунікативній діяльності) [14].

Для розуміння сутності поняття «іншомовна освіта студентівмедиків» (рис. 3.) у Великій Британії наводимо виокремлені в педагогічній науці визначення поняття іншомовної освіти [12, с. 7]. 


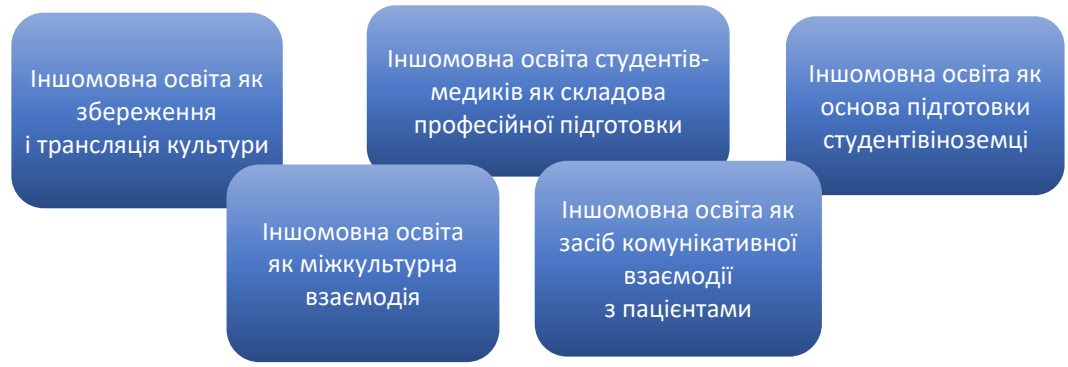

\section{Рис. 3. Іншомовна освіта студентів-медиків як складова професійної підготовки}

2. Іншомовна освіта як цінність може бути розглянута на трьох рівнях: на рівні цінностей-відносин, що розкривають значення і сенс комунікативних відносин і комунікативної поведінки; на рівні цінностей-знань, котрі розкривають значення і сенс культурологічних, країнознавчих знань, при цьому іноземна мова позиціонується як феномен культури, тому що мова $є$ знаряддям творення, розвитку, збереження i трансляції культури, фіксує певний світогляд; як елемент культури, бо займає перше місце серед національно-специфічних компонентів культури, зберігає культурні цінності в лексиці, граматиці, ідіоматиці, в фольклорі, в художній і науковій літературі, в формах усного та писемного мовлення; як «перехрестя культур», тому що кожне іноземне слово відображає іноземний світ і іноземну культуру; як засіб трансляції культури, тому що $є$ способом передачі інформації, засобом прилучення до людської культури, взятої в аспекті соціального досвіду; на рівні цінностей-якостей, що розкривають значення і сенс індивідуальних, особистісних якостей особистості.

3. Іншомовна освіта розглядається як діяльність, що характеризується наступними параметрами: статусним становищем як форми відношення суб'єкта до полікультурного соціуму, до взаємодії різних культур і субкультур; наявністю суб'єкт-суб'єктних і суб'єкт-об'єктних відносин у процесі навчання міжкультурної комунікації; відкритістю і універсальністю даної діяльності як системи; штучністю і кільцевою структурою діяльності; актуальністю і ситуативністю розв'язуваних педагогічних. Крім того, іншомовна освіта характеризується як пізнавальна, ціннісноорієнтаційна, комунікативна, естетична, і, відповідно, перетворювальна діяльність. 
4. Результатом іншомовної освіти $€$ сукупність компетенцій: комунікативна - здатність засобами мови здійснювати мовну діяльність відповідно до цілей спілкування в рамках тієї чи іншої сфери діяльності; міжкультурна , котра є показником сформованості здатності людини брати участь в міжкультурній комунікації; соціокультурна, що передбачає знання в області проявів іншої культури, вивчення традицій країни; навчально-пізнавальна, що дозволяє удосконалювати навчальну діяльність 3 оволодіння іноземною мовою $[12$, с. 6].

Іншомовна освіта у медичних закладах вищої освіти Великої Британії забезпечує міжнародну академічну мобільність. Орієнтуючись на результат іншомовної освіти як систему компетентностей, зазначимо, що сучасна підготовка з іноземних мов в медичних закладах вищої освіти характеризується особливим лінгводидактичними особливостями формування професійної іншомовної компетентності: зміна соціального замовлення щодо найбільш професійно значущих областей володіння іноземною мовою i культурою; перехід сучасної системи освіти на принципи Болонської конвенції, що мають на увазі інтернаціоналізацію змісту навчання, участь студентів в програмах міжнародної академічної мобільності і, відповідно, уточнення цілей іншомовної підготовки; загострення внутрішніх і зовнішніх міжетнічних і межконфесійних конфліктів, що перешкоджають міжкультурній взаємодії; крайня обмеженість за часом і переповнення по кількості програмно закладених одиниць змісту; характерна для більшості педагогів недостатність лінгвокраїнознавчої компетентності, необхідної для підготовки студентів до міжкультурної взаємодії, метою якої є досягнення загальних професійних і особистісних цілей. В даних соціальноекономічних умовах основною метою мовної підготовки у 3 ВО науковцями визначено формування міжкультурної компетентності як студентів, так і викладачів, котра має на меті одночасний розвиток комунікативної і стратегічної компетентності. Важливим $\epsilon$ визначення співвідношення факторів їх формування - чинників, характерних для конкретних умов і відповідно до цілей і завдань того чи іншого проекту міжнародної академічної мобільності [13]. Сутність поняття іншомовна освіта передбачає певну систему взаємопов'язаних компонентів професійно-орієнтованої іншомовної освіти, спрямованої на розвиток мовної особистості студентів медичних спеціальностей, розкривається в таких підструктурах: соціальна складова: розуміння особистістю впливу культури на 
поведінку ії представників; перетворення даних знань в ефективну практичну взаємодію з тими, хто відрізняється від неї; психологічна складова: усвідомлення відмінності представників інокультури (стереотипи, менталітет); збагачення особистості в результаті усвідомлення цінностей іншої культури; вміння успішно пристосуватися й адаптуватися до певних культурних умов; лінгвістична складова: знання і застосування мовних особливостей i механізмів, що дозволяють здійснювати успішне міжкультурне професійне спілкування; методична складова: сукупність педагогічних засобів, що реалізують цілі, зміст і методи формування міжкультурної компетенції в процесі навчання іноземної мови (див. рис. 4).

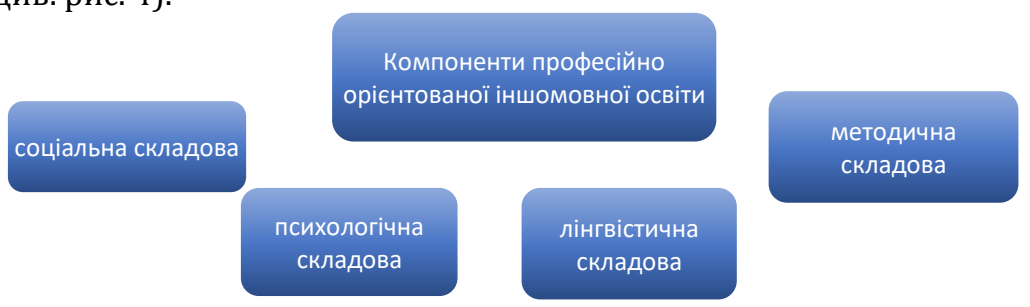

\section{Рис. 4. Компоненти професійно-орієнтованої іншомовної освіти}

Одночасно можемо визначити структуру міжкультурної компетентності студентів медичних спеціальностей, котра включає в себе такі компоненти: когнітивний - сукупність знань професійної лексики, термінології та особливостей поведінки в спілкуванні 3 представниками іншої культури; мотиваційний - мотиваційна спрямованість на міжнаціональну комунікацію, професійний інтерес; потреба у визнанні і самоактуалізації; ціннісний - вищі цінності, що відображають цінності міжкультурної комунікації: толерантність, рівноправність традицій, етика, повага і терпимість до «індивідуальності» культур; діяльнісний - вміння оперувати наявними знаннями в умовах реальної комунікації з представниками досліджуваної культури [13]. Дослідження доводить, що сучасне розуміння сутності та структури поняття іншомовної освіти в основі має ті позитивні соціальні зрушення, які безпосередньо визначають вимоги до професійної освіти, у тому числі до майбутніх лікарів. Охарактеризуємо основні напрями модернізації професійної іншомовної освіти у Великій Британії з метою розгляду можливостей і доцільності використання такого досвіду в українських 
університетах. На кінець XX - початок XXI ст. сформувалася потужна школа науковців-компаративістів, які досліджують проблеми розвитку освіти у світовому та Європейському просторі (Н. Дічек, В. Жуковський, К. Корсак, В. Кравець, Н. Лавриченко, О. Локшина, 0. Овчарук, А. Сбруєва); дослідження 3 проблем формування професійної іншомовної компетентності Р. Гришкова; Е. Комарова, Б. Далхаус, та ін.). Іншомовна освіта широко розробляється вітчизняними та зарубіжними науковцями. Проблеми психологічних основ навчання іноземних мов (Б. Бєляєв); наукові дослідження 3 проблем навчання іноземної мови у середніх і вищих закладах освіти (I. Берман, В. Бухбіндер, Ю. Жлуктенко, Г. Китайгородська, М. Ляховицький, Л. Морська, С. Ніколаєва) і роботи з іншомовною літературою (А. Вейзе, В. Григоров, О. Пумпянський, В. Судовцев, 0. Троянська, С. Фоломкіна); праці з вивчення наукового медичного тексту (Л. Абраменко, М. Лаврик, Д.-Е. Чабнер) [10; 11].

Автор описує практику вивчення мов у Великій Британії, управління соціальними групами. Б. Сполскі ставить собі за мету спробу зрозуміти, що таке мовна політика та як на неї можна вплинути; визначає Питання розвитку вищої школи та професійної освіти у зарубіжжі, а також актуальні проблеми її реформування в Україні розробляють В. Базуріна; Т. Бондар; А. Грітченко; П. Кряжев; О. Кузнецова; А. Лукановська; О. Огієнко; Д. Пащенко; Г. Поберезська, 0. Тарнопольський [17] та ін.

Значимість іншомовної освіти у Великій Британії підсилюється тенденцією використання ії у науковому обігу. Останнім часом англійська мова набула широкого розповсюдження у медичних дослідженнях. Так, 72\% медичних статей, наведених у Index Medicus (покажчик усіх статей, опублікованих у медичних журналах у всьому світі), були написані англійською мовою. Зростає світова тенденція до видання вітчизняних медичних журналів англійською мовою для розширення кола читачів. У Великій Британії науковці по-різному ставляться до сутності іншомовної освіти майбутніх фахівців, у тому числі майбутніх лікарів. Так, Х. Футітт у книзі «Національна мовна стратегія у вищій освіті» (London, 2005) [15] наводить результати дослідження, що було проведено з метою доповнення Національної мовної стратегії елементами про вищу освіту та заохочення співпраці ЗВО для підтримки стратегії в цілому. Головною метою вищої освіти як частини Стратегії розглядається підвищення кількості студентів, які би вивчали іноземні мови на рівні університетів у Великій Британії. Завданнями проекту були: ознайомлення 
3 національними/ регіональними тенденціями у мовному забезпеченні 3ВО, встановлення інституційних чинників, котрі сприяли поглибленню вивчення мов у ЗВО, визначенню тенденцій розвитку професійної мови у ЗВО. Практику іншомовної освіти як основи для розробки моделі сучасної національної мовної політики та основних методів її контролю у Великій Британії представлено у праці Б. Сполскі «Мовна політика» (Cambridge, 2004) [16].

Автор описує практику вивчення мов у Великій Британії, управління соціальними групами. Б. Сполскі ставить собі за мету спробу зрозуміти, що таке мовна політика та як на неї можна вплинути; визначає структуру і природу мовної політики, досліджує обговорення та дискусії на тему мовної політики та описує взаємодію між різними її компонентами. Р. Левіт, Б. Джанта, А. Шехабі у дослідженні «Мова має значення: постачання та попит для дослідників, що народились та отримали освіту в Британії навичок знання інших мов, крім англійської» (RAND Corporation, 2009) [16] обгрунтовують роль мовних навичок в академічних дослідженнях в гуманітарних та суспільних науках у університетах Великої Британії. Ця робота опирається на попередню роботу Британської академії, присвячену стану вивчення мови в освіті у Великій Британії, та ії занепокоєнню щодо зниження здатності громадян, що народилися та отримали вищу освіту, використовувати мовні навички.. У дослідженні Р. Балфора «Мовна політика університетів, інтернаціоналізм, мультилінгвізм та мовний розвиток в Південній Африці та Об'єднаному Королівстві» (Cambridge, 2006) [15] розглядається законодавство щодо мовної політики та вибору мови у Великій Британії та Південній Африці. У роботі показано, що порівняння між Південною Африкою та Об'єднаним Королівством $€$ релевантним та привабливим, не в останню чергу через те, що обидві країни реагують на поінформованість про багатомовність та інтернаціоналізм як в системі середньої, так і в системі вищої освіти, хоча і по-різному і з різними ефектами. У роботі вивчається, як може сприяти або перешкоджати мовна політика розвитку мови та вибору її у закладах вищої освіти у Великій Британії та Південній Африці. У праці «Мови мінорних спільнот у вищій освіті: на шляху усвідомлення потенціалу» (University of Southampton, 2008) [19] Мак Пейк Дж. досліджує навчання мов окремих спільнот країни, які визначаються як «всі мови, що використовуються в суспільстві, крім домінуючої, офіційної або національної мови». Мета даного дослідження полягала в тому, щоб 
визначити забезпеченість викладання мов мінорних спільнот країни у вищих навчальних закладах Англії та вирішити як необхідно розвивати даний напрямок для задоволення нових потреб.

У Великій Британії науковці по-різному ставляться до сутності іншомовної освіти майбутніх фахівців, у тому числі майбутніх лікарів. Так, Х. Футітт у книзі «Національна мовна стратегія у вищій освіті» (London, 2005) [15] наводить результати дослідження, що було проведено з метою доповнення Національної мовної стратегії елементами про вищу освіту та заохочення співпраці ЗВО для підтримки стратегії в цілому. Головною метою вищої освіти як частини Стратегії розглядається підвищення кількості студентів, які би вивчали іноземні мови на рівні університетів у Великій Британії. Завданнями проекту були: ознайомлення 3 національними/ регіональними тенденціями у мовному забезпеченні 3В0, встановлення інституційних чинників, котрі сприяли поглибленню вивчення мов у ЗВО, визначенню тенденцій розвитку професійної мови у ЗВО. Практику іншомовної освіти як основи для розробки моделі сучасної національної мовної політики та основних методів іï контролю у Великій Британії представлено у праці Б. Сполскі «Мовна політика» (Cambridge, 2004) [16].

Автор описує практику вивчення мов у Великій Британії, управління соціальними групами. Б. Сполскі ставить собі за мету спробу зрозуміти, що таке мовна політика та як на неї можна вплинути; визначає структуру і природу мовної політики, досліджує обговорення та дискусії на тему мовної політики та описує взаємодію між різними її компонентами. Р. Левіт, Б. Джанта, А. Шехабі у дослідженні «Мова має значення: постачання та попит для дослідників, що народились та отримали освіту в Британії навичок знання інших мов, крім англійської» (RAND Corporation, 2009) [17] обгрунтовують роль мовних навичок в академічних дослідженнях в гуманітарних та суспільних науках у університетах Великої Британії.

Ця робота опирається на попередню роботу Британської академії, присвячену стану вивчення мови в освіті у Великій Британії, та іiї занепокоєнню щодо зниження здатності громадян, що народилися та отримали вищу освіту, використовувати мовні навички.. У дослідженні Р. Балфора «Мовна політика університетів, інтернаціоналізм, мультилінгвізм та мовний розвиток в Південній Африці та Об'єднаному Королівстві» (Cambridge, 2006) [18] розглядається 
законодавство щодо мовної політики та вибору мови у Великій Британії та Південній Африці. У роботі показано, що порівняння між Південною Африкою та Об'єднаним Королівством $є$ релевантним та привабливим, не в останню чергу через те, що обидві країни реагують на поінформованість про багатомовність та інтернаціоналізм як в системі середньої, так і в системі вищої освіти, хоча і порізному і з різними ефектами.

У роботі вивчається, як може сприяти або перешкоджати мовна політика розвитку мови та вибору ії у закладах вищої освіти у Великій Британії та Південній Африці. У праці «Мови мінорних спільнот у вищій освіті: на шляху усвідомлення потенціалу» (University of Southampton, 2008) [19] Мак Пейк Дж. досліджує навчання мов окремих спільнот країни, які визначаються як «всі мови, що використовуються в суспільстві, крім домінуючої, офіційної або національної мови». Мета даного дослідження полягала в тому, щоб визначити забезпеченість викладання мов мінорних спільнот країни у вищих навчальних закладах Англії та вирішити як необхідно розвивати даний напрямок для задоволення нових потреб.

\section{Висновки}

Проблема професійної підготовки майбутніх лікарів у контексті інтеграційних процесів у медичній освіті Великої Британії пов'язана 3 дослідженням питання основних стратегій розвитку медичної освіти у діяльності міжнародних організацій, що передбачає запровадження державних програм щодо покращення здоров'я населення та доступності послуг з охорони здоров'я на основі підвищення якості та ефективності підготовки медичних працівників.

Визначено, що важливим напрямом стратегій розвитку медичної освіти є процес гуманізації медичної допомоги на основі втілення міжнародноправових стандартів у законодавство країни та забезпечення прав і свобод людини. Важливим чинником у цьому процесі $\epsilon$ міжнародне співробітництво держав у галузі прав людини, що відбувається у формі прийняття певних стандартів стосовно змісту правового статусу індивіда та реалізації державами зобов'язань стосовно дотримання цих стандартів у своєму внутрішньому законодавстві і у повсякденній діяльності. Таким чином, діяльність міжнародних організацій та основні положення міжнародних документів щодо охорони здоров'я мають 
методологічне значення для дослідження системи медичної освіти у Великій Британії.

Досліджено, що в епоху глобалізації та інтернаціоналізації європейської вищої освіти гостро постає питання взаємного визнання навчальних планів і програм, кваліфікаційних рівнів освіти, оцінок тощо. Важливим $\epsilon$ порозуміння стосовно принципів контролю якості освіти, у питаннях ліцензування і акредитації вищих навчальних закладів різних типів і рівнів у країнах світу. Відповідно, серед новітніх тенденцій розвитку вищої школи як інтернаціонального явища особливе місце займає інтеграція (наприклад, євроінтеграція) вищої освіти, що має на меті створення єдиного освітнього простору.

\section{Література}

1. Dahlhaus B. Fertigkeit Hören. München: Goethe-Institut, 1994. $192 \mathrm{~s}$

2. Зіньковський Ю. Стандартизація освіти як імператив реформування вищої школи. Вища школа. 2010. № 1. С. 24-31.

3. Верхогляд О., Романовська Ю., Романовський О. Проблеми міжнародної співпраці у сфері вищої освіти: контроль за якістю освіти. Національний і міжнародний аспекти. Вища школа. 2010. № 1. C. $15-24$.

4. Реформа и развитие высшего образования. Программный документ. Париж : ЮНЕСКО, 1995. 56 с.

5. Стандарти медичної освіти й професійної підготовки у Великій Британії. URL: https://en.wikipedia.org/wiki/Medical_ education_in_the_United_Kingdom (дата звернення: 14.03.2017).

6. Investigating and acting on concerns about doctors. URL: https://www.gmc uk.org/about/role.asp (дата звернення: 11.10.21).

7. Сагинова О. В. Проблемы и перспективы интернационализации высшего образования (на примере Российской экономической академии им. Г.В. Плеханова). URL: http://www.edit.muh.ru/content/ conf/Saginova.htm (дата звернення: 14.11.2016).

8. Стандарти та норми забезпечення якості в Європейському просторі вищої освіти. Основні засади розвитку вищої освіти України в контексті Болонського процесу / упоряд.: М. Ф. Степко, Я. Я. Болюбаш, В. Д. Шинкарук та ін.; за ред. С. М. Ніколаєнка. Тернопіль : Вид-во ТНПУ ім. В. Гнатюка, 2006. Ч. 3: Документи і матеріали. С. 83-109.

9. Lambert T. W., Goldacre M. J., Davidson J. M. et al. Graduate status and age of entry to medical school as predictors of doctors' choice of longterm career. Medical Education. 2001. Vol. 35. P. 450-454.

10. Лазаренко О. В. Тенденції становлення та розвитку іншомовної освіти в університетах Великої Британії. URL: http:// 
www.rusnauka.com/31_PRNT_2010/Pedagogica/73987.doc.htm (дата звернення: 20.08.2016).

11. Пассов Е. И. Программа-концепция коммуникативного иноязычного образования. Москва, 2000.170 с.

12. Ветчинова, M. Н. Теория и практика иноязычного образования в отечественной педагогике второй половины XIX начала XX века : автореф. дис. ... д-ра пед. наук. Москва, 2009. 48 с.

13. Крупченко А. К., Кузнецов А. Н. Основы профессиональной лингводидактики: монография. Москва : АПКиППРО, 2015. 232 с.

14. Суворова С. Л., Овсянникова О. Е. Актуальные проблемы иноязычного образования в вузе. URL: http://shgpi.edu.ru/files/ nauka/vestnik/2013/2013-4-51.pdf (дата звернення: 11.10.2021).

15. Foreign Languagesin the School Curriculum. A Draft Statement of Policy. DES and Welsh Office. June, 1986.

16. Stacey M. Regulating British Medicine: the General Medical Council. Chichester : JohnWiley \& Sons, 1992. 243 p.

17. Learning and Skills for Sustainable Development. Developing a Sustainability Literate Society. Guidance for Higher Education Institutions. URL: www.forumforthefuture.org.uk (дата звернення: 11.11.2016).

18. Ball S. Education policy in England. Changing modes of regulation: 1945-2001. Changes in Regulation Modes and Social Reproduction of Inequalities in Education Systems: A European Comparison. London: Institute of Education and King's College, University of London, 2002. $44 \mathrm{p}$.

19. Medical Career Structure. General Medical Council. URL: http://www.gmc-uk.org/Medical_career_structure_doctors_in_training. pdf_25417075.pdf (дата звернення: 27.09.2021). 